\title{
Corporate Social Responsibility, Investment Decisions, and Managerial Ownership on Value of The Company : Evidence From Indonesia
}

\author{
Kenny Ardillah ${ }^{1}$, Thenia ${ }^{2}$ \\ ${ }^{1}$ Institut Teknologi dan Bisnis Kalbis, ${ }^{2}$ Universitas Matana \\ Correspondent: 120617@,lecturer.kalbis.ac.id ${ }^{1}$, thenia@matanauniversity.ac.id ${ }^{2}$
}

$\begin{array}{ll}\text { Received } & \text { : August 08, } 2021 \\ \text { Accepted } & \text { : August 25, } 2021 \\ \text { Published } & \text { : October 31, } 2021\end{array}$

Citation: Ardillah, K., Thenia. (2021). Corporate Social Responsibility, Investment Decisions, and Managerial Ownership on Value of The Company : Evidence From Indonesia. Ilomata International Journal of Tax \& Accounting 2(4),268-285.

https://doi.org/10.52728/ijtc.v2i4.341

\begin{abstract}
This study aims to prove the influence of corporate social responsibility, investment decisions and managerial ownership on value of the company. Theories used in this research are agency theory and signal theory. This research was done on all manufacturing companies listed on the Indonesia Stock Exchange for the period of 2016-2018. The sampling method used is purposive sampling technique and the data analysis method used is multiple linear regression analysis. The results of this study show that corporate social responsibility and managerial ownership have no influence on value of the company, while investment decisions have a positive influence on value of the company. Few suggestions for the further research are adjust research periods, use other criteria of sample, use other indicators such as funding decisions, company size, other corporate governance indicators, or use other methods to measure value of the company.
\end{abstract}

Keywords: Corporate Social Responsibility, Investment Decisions, Managerial Ownership, Value Of The Company

\begin{tabular}{l|l|l|l}
\hline This is an open access article under the \\
CC-BY 4.0 license.
\end{tabular}

\section{INTRODUCTION}

Corporate social responsibility is a form of private company contribution that is philanthropic or charitable with the aim of making social contributions ethically. Although initially CSR was an internal company policy, now various national and international laws have developed CSR activities as an obligation for businesses and industries around the world. The company's CSR activities at least have a positive social and economic impact on the people living around the company's operational areas, local communities in sub-districts, districts and provinces. Multinational companies have CSR programs that provide social impacts regionally, nationally, and even internationally. (Pavez et al., 2020; Rahdari et al., 2020)

Corporate social responsibility is an effort to improve the company's positive image. In addition to providing benefits to the community, CSR is also important for companies. CSR activities have many benefits for companies such as strengthening the relationship between employees and the company, increasing employee morale, and making the company more connected to the people who live around the company's offices. (Elgebeily et al., 2021; Jarjir et al., 2020) 
Before companies implement CSR, companies must have responsibilities to employees and shareholders. Therefore, companies that implement CSR programs usually have completed their responsibilities to employees and shareholders so that they can provide benefits to the community. In other words, CSR strategy is a program implemented by large companies with work areas covering regional, national or international areas. The more successful a company is, the more responsibility it has to set standards of ethical behavior for its colleagues, competitors, and industry. (Abdelfattah \& Aboud, 2020; Tarczynski et al., 2020)

The company will always strive to achieve its goals, both short-term and long-term goals. The short-term goal is that the company can get the maximum profit possible by utilizing the resources owned by the company, while related to the long-term goal, the company will always try to maximize the value of the company (Meidiawati \& Mildawati, 2016). Currently, business competition continues to increase. In its development, the company always strives to maintain its business excellence to increase the value of the company. With this guarantee, shareholders will not hesitate to invest their capital (Puspaningrum, 2017)

Value of the company is the worth that forthcoming purchasers will pay if the company is sold (L. Dewi \& Wirasedana, 2018). The value of the company is likewise reflected in the stock price which is steady and has expanded in the long haul. The higher the stock value, the higher the value of the company. High value of the company is the craving of company proprietors, on the grounds that a high value will demonstrate high investor flourishing. Value of the company is an investor's view of the company's degree of achievement which is firmly identified with its offer value (Rinnaya et al., 2016).

In investing, investors and potential investors need to collect information as one of the basic considerations in making investment decisions in the capital market. The capital market is a means of channeling funds from investors to parties who need funds, namely companies through the sale of shares and bonds. With the capital market, investors can invest their funds by buying company shares in the hope of obtaining a return in the form of dividends or capital gains. Meanwhile, issuers can use these funds for the benefit of the company without having to wait for the availability of funds from the company's operations (Meidiawati \& Mildawati, 2016)

The movement of the Stock Price Index (CSPI) on the Indonesia Stock Exchange throughout 2018 was affected by various sentiments, both from within and globally. JCI actually recorded a decline of 3.02 percent year to date (ytd). There was a decline in all sectors of the manufacturing industry. In the basic and chemical industry sectors, there was no significant decline between 2016 and 2017 of 3.90 percent, while the decline from 2017 to 2018 was 4.05 percent. In the various industrial sector, there was a very significant decline from 2016 to 2017 which was 28.87 percent and there was a slight increase between 2017 and 2018 of 0.19 percent. An increase also occurred in the consumer goods industry sector between 2016 and 2017 which was 10.55 percent, but there was a very significant decrease from 2017 to 2018 of -33.32 percent.

To achieve the goals of a company, synergy and reciprocal relationships are needed between the company and the community, investors and employees of course. One way that can be done is by interacting between the company and the environment, because the environment contributes to the sustainability of the company and also social welfare. In the period of individuals who are beginning to think often about the climate, corporate social responsibility is something that should be done and not simply an intentional decision for companys. The company's commitment to 
execute corporate social responsibility has been directed in Law No. 40 of 2007 Article 74 of the Limited Liability Company Law. Numerous advantages acquired by the company in the execution of corporate social responsibility, among others, items are progressively preferred by buyers and companys are drawn in by investors. Corporate social responsibility can be utilized as another showcasing device for companys on the off chance that it is carried out economically. By executing corporate social responsibility, the company's picture will be better so shopper faithfulness is higher. Subsequently, corporate social responsibility assumes a significant part in expanding the worth of the company because of expanding company deals via completing different social exercises in the general climate (Wulandari et al., 2016).

But in reality, when an industry develops, many companies only focus on being an company that only seeks economic benefits and does not care about the impacts, resulting in social inequality and environmental damage. For example, the case of environmental problems due to the company's production process in Indonesia that occurred in the Bandung Regency area, a number of textile industries around Majalaya that dispose of waste into the Citarum river which often disturbs the health of the surrounding community and pollution that occurs in the Ciujung River, waste from the PT Indah Kiat Pulp paper mill. \& Paper which is located in Serang Regency, air pollution by cigarette factories in Kediri, the emergence of active radio due to metal processing waste in Tegal Regency and other pollution. Every company should not only think about obtaining material benefits, at least the company is able to provide useful and beneficial things for external parties of the company, such as the community, social and environment in which the company operates (Astuti \& Nugrahanti, 2015).

The investment decision is a vital factor in the company's financial function, where the higher the investment decision has been decided by the company, the higher the company's chance to get an enormous pace of return. Companys that have high investment decision will actually want to influence investors' comprehension of the company, so it can build the interest for the company's shares. Along these lines, the higher the investor's interest in putting resources into the company, the speculation choice affects expanding the value of the company (Pertiwi et al., 2016)

The reason for settling on investment decisions is to get a huge benefit with least risk in order to enhance the value of the company. The right investment decision can affect the value of the company by focusing on various investments that get an excess. The excess acquired by the company will add to trade out for cash inflow, which is then aggregated as company benefit. The other way around, if the investment decision doesn't influence the value of the company, it very well may be deciphered that the company as of now has a shortage on various of investments which causes a a lessening in value, accordingly diminishing the value of the company (Suryandani, $\underline{2018)}$

Managerial ownership is the participation of the management who actively participates in making company decisions (managers, directors or commissioners) and is also given the opportunity to participate in owning company shares (shareholders). Managerial ownership is often associated as an effort to increase the value of the company because managers apart from being management, as well as company owners will feel directly the consequences of the decisions they make so that managers will not take actions that only benefit managers (Suastini et al., 2016).

In increasing the value of the company, agency conflicts often occur, namely conflicts of interest between shareholders and managers. Corporate managers tend to pursue their own personal goals, 
for example to get the highest possible bonus. Managers will only focus on projects and investments that will provide large returns in the short term rather than maximizing shareholder wealth by investing in projects that are profitable in the long term. However, for shareholders, it will increase costs for the company which can cause a decrease in profits and affect the stock price so that it can reduce the value of the company. The proportion of managerial ownership can reduce the agency problem and indicate a common interest between management and shareholders. In addition, increasing share ownership by management will align its position with shareholders so that management will be motivated to take decisions that increase value of the company (Puspaningrum, 2017).

This research is a replication of (Murnita \& Putra, 2018), (Wiguna \& Yusuf, 2019) and (Somantri \& Sukardi, 2019) research. The differences between this study and previous research include 1) the sample companies used in this study are manufacturing industry sector companies listed on the Indonesia Stock Exchange in 2016-2018. The reason for choosing the manufacturing industry sector is because among the nine company sectors listed on the Indonesia Stock Exchange, the manufacturing industry sector has tighter and stronger competitive competence, has a large number of registered companies and has a fairly close relationship with consumers because most of their products are almost always used by consumers. 2) the period used in this study is between 2016-2018. The reason for the research period is 3 (three) years in order to provide valid and coherent data so as to obtain relevant research results. The purpose of this study is to prove the influence of corporate social responsibility, investment decisions, and managerial ownership on value of the company.

\section{Agency Theory}

Agency theory describes the relationship between management (agent) and shareholders (principal). Where the manager as an agent must be able to run a company with the best decisions to increase the wealth of the principal, namely the shareholders. However, sometimes the shareholders cannot oversee all the decisions and activities carried out by managers, so it will be a threat if what is done by the managers is not for their own welfare. Quality financial statement information can assist in making decisions for investors and potential investors (Rahayu \& Sari, 2018).

Agency issues for the most part happen when company's manager have a share ownership extent of under $100 \%$ with the goal that directors tend to act to seek after their own advantages in settling on organization monetary choices and not based on expanding value of the company (L. Dewi \& Wirasedana, 2018). With managerial ownership, manager will attempt to work as per the desires of the shareholders so managers will likewise be roused to further improve performance which will affect expanding investor certainty and value of the company (Wiguna \& Yusuf, 2019)

\section{Signalling Theory}

Signaling theory clarifies that organizations are urged to have the option to give data on their financial reports to external parties (investors and creditors) to prevent information asymmetry that may occur, because companies know more data about the organization's possibilities than outside parties, both creditors and investors. The data given by the organization to external parties is relied upon to lessen the occurrence of information asymmetry between internal parties and outside parties just as to expand the value of the company. Information distributed as a declaration will give a signal to investors. On the off chance that the declaration contains a positive value, the 
market will react well to the information so that there will be changes in sales volume and changes in stock prices where this can influence the value of the company which is reflected in the increment in the organization's stock value (Widiastari \& Yasa, 2018).

Signal theory shows how good quality companies can intentionally give signals to investors, so investors are able to distinguish good quality companies and poor quality companies. In addition, the information that companies must disclose is information about corporate social responsibility or what is often referred to as corporate social responsibility. Information on corporate social responsibility is contained in the company's annual report or a separate report on corporate social responsibility. Every company that carries out social responsibility activities is expected to improve the company's image and also the value of the company. The consideration of using this theory is because this theory is able to provide encouragement for companies to provide information to external parties that influence decision making which will later affect the value of the company and also affect changes in the company's stock price (Murnita \& Putra, 2018).

\section{Corporate Social Responsibility}

According to The International Company of Employers, corporate social responsibility is defined as voluntary activities that are positive for companies in various fields, both economic, social and environmental. It can be considered as an aspect of business strategy with the aim of making a profit and is a form of interaction between the company and the social environment. Corporate social contributions can be implemented in several ways, including 1) financial donations, such as support for cultural performances. 2) donations for people with disabilities or religious groups and donations to universities. 3) social voluntary activities, such as building a house. 4) employ foreigners, disabled people, and women to ensure social justice. 5) protect the environment and so on (Chung et al., 2018).

If a company discloses social responsibility in a sustainable and consistent manner, investors will appreciate and give a positive appreciation which is displayed by the expansion in the organization's stock price and furthermore the expanding value of the company as an indication of the endurance of an organization later on (Murnita \& Putra, 2018). Corporate social responsibility is is unveiled in a report called sustainability report. Corporate social responsibility can be practical if the program made by an organization is actually a joint responsibility from all components inside the actual organization (Wulandari et al., 2016). Corporate social responsibility reporting is usually used as a mechanism by which companies share information with shareholders about the company's approach to issues related to the environment, society, employees and consumers (Singh et al., 2017).

\section{Investment Decision}

Investment is the connecting of assets in the long haul to produce profits later on. Investment decisions are vital in light of the fact that they are the center of all financial analysis which will eventually influence the accomplishment of organization objectives. The current investment opportunities influence the value of the company organization which is essentially shaped through the financial stock market value. Furthermore, investment decision making is also very important for the survival of the organization concerned in light of the fact that it includes the assets utilized for investment, the sort of investment to be made and the different risk that can be created (L. Dewi \& Wirasedana, 2018). Investment can come from inside or outside the company. Investments originating from within the company include cash, marketable securities, trade 
receivables, inventories and others. Meanwhile, investments originating from outside the company include equipment, land, buildings, machinery, vehicles and so on (Tanto et al., 2019).

Investment decisions are decisions taken as an alternative for the company to issue funds outside of operational activities which can then provide benefits to the company in the future. Investment decisions have a long term, so the decisions taken must be considered properly because they have long-term risks. If the organization can settle on the right investment choices, the organization will acquire benefits and the organization's resources will create ideal execution to give a positive sign to investors which will expand stock price and increment value of the company ( $\underline{\text { Suryandani, 2018). }}$. The investment made by the company certainly aims to prosper shareholders, both now and in the future (Somantri \& Sukardi, 2019). Investment decisions are also considered as a decision made by the company in spending its funds in the form of certain assets in the hope of getting profits in the future (Suroto, 2015).

\section{Managerial Ownership}

Managerial ownership is the level of share's possession claimed by directors, managers and commissioners which can be found in the financial statements. Managers act all the more cautiously with this share ownership in light of the fact that they likewise bear the outcomes of the choices that have been taken. Companies with managerial ownership will positively adjust their inclinations as managers and also as shareholders. Managerial ownership will help the unification of interests between managers and shareholders, straightforwardly feel the advantages of the choices taken and bear the losses as a result of settling on wrong choices. (Widianingsih, 2018)

In the company's financial statements, managerial ownership is demonstrated by the enormous level of organization share's proprietorship by managers. Information on share ownership by the manager unveiled in the notes to the financial statements By giving management the opportunity to be involved in the ownership of the company's shares, it is expected that management will act carefully because whatever decisions are made, they will also bear the consequences. Management is also expected to be motivated to improve their professionalism which will have an impact on increasing company performance and value (Hidayah, 2017).

\section{Value of The Company}

Value of the company can be characterized as a specific condition that has been accomplished by an organization as an outline of public confidence in the organization subsequent to going through a cycle of activities for quite a while, since the organization was established as of recently. Expanding the value of the company is an accomplishment, in light of the fact that expanding the value of the company is the thing that the proprietors need and with the increment in the value of the company. The welfare of the proprietors will likewise increment because a high share price will make the value of the company additionally high. The higher the value of the company, the higher the prosperity of shareholders (Rinnaya et al., 2016). However, stock prices in the capital market are formed based on investor supply and demand, so the stock price is a fair price that can be used as value of the company (Sudarma \& Darmayanti, 2021).

Value of the company is is a marker for the market in evaluating the organization as a whole. the thing that makes the value of the organization a significant idea for investors. The value of companies that have opened up to the public in the capital market is reflected in the stock price, if the share price increases, the value of the company additionally increments, while the value of 
companies that have not opened up to the public is reflected in the value of company resources, business hazard level, organization possibilities, the executives, business climate and different variables. The stock price can can be supposed to be a marker of the organization's prosperity, where market strength in the stock trade is shown by the deal and acquisition of shares in the capital market (Khoirunnisa, 2018).

\section{Hypothesis Development}

The Influence of Corporate Social Responsibility on Value of The Company

Corporate social responsibility is a type of duty to do the activities for environment and give impacts around the organization. Organizations that do social responsibility are viewed as ready to disclose a decent commitment to the public and can be liable for their activities and impacts on the surrounding environment. The execution of corporate social responsibility will likewise persuade and give a signal to investors that the organization will actually want to guarantee its endurance later on while expanding the value of the company (Murnita \& Putra, 2018). This statement is supported by research conducted by Dewi \& Sanica (2017) and Andreas \& Adiputra (2019) which found that corporate social responsibility has a positive influence on value of the company.

Ha1: Corporate social responsibility has a positive influence on value of the company

\section{The Influence of Investment Decisions on Value of The Company}

Investment decisions are significant choices in the management function in finance because they involve how to distribute organization reserves, both from inside and outside the organization in regards to different types of venture choices with similar objective of acquiring more noteworthy benefits later on (Suryandani, 2018). High investment is a sign of organization pay development which is viewed as uplifting news by investors in impacting impression of organization execution which will eventually influence value of the company (Suroto, 2015). This statement is supported by research conducted by ( $\underline{\text { Suroto, 2015) }}$ and (Tanto et al., 2019) which found that investment decisions have a positive influence on value of the company.

\section{The Influence of Managerial Ownership on Value of The Company}

Managerial ownership is one of the share proprietorship structures that can influence the motivating forces for the board to practice the wellbeing of investors. Be that as it may, managers tend to utilize high obligation not based on amplifying the value of the company, however for their own advantages. Conflict between management and company owners is called agency conflict. The managerial ownership mechanism can minimize conflicts of interest that arise from the agency relationship between shareholders and management. Managerial ownership is able to control and reduce earnings manipulation behavior by managers, so that the quality of reported earnings can increase and also have an impact on increasing value of the company (Sudarma \& Darmayanti, 2021). This statement is supported by research conducted by (Gayatri et al., 2016) and (Sudarma \& Darmayanti, 2021) which found that managerial ownership has a positive influence on value of the company

Ha3: Managerial ownership has a positive influence on value of the company

\section{METHOD}


Corporate Social Responsibility, Investment Decisions, and Managerial Ownership on Value of The Company : Evidence From Indonesia

Ardillah \& Thenia

The population used in this study were all manufacturing companies listed on the Indonesia Stock Exchange for the 2016-2018 period, totaling 166 companies. The sample of this research is manufacturing companies listed on the Indonesia Stock Exchange in 2016-2018 that meet the criteria for sampling. Sampling in this study was conducted using non-probability sampling technique. One of the sampling techniques included in the nonprobability sampling technique is the purposive sampling method (Sugiyono, 2016: 84-85). The criteria applied in the sampling of this research are as follows.

1. Manufacturing organizations that have been recorded on the Indonesia Stock Exchange and distributed a yearly report sequentially during the 2016-2018 period.

2. Manufacturing organizations that distribute their yearly reports in rupiah.

3. Manufacturing organizations that have total information identified with the factors utilized in the investigation such as corporate social responsibility and managerial ownership.

4. Companies that have net income during the 2016-2018 period.

The purposive testing strategy utilized in this investigation brought about 29 organizations that met the measures in this examination. The aftereffects of the example choice are introduced in table 2 underneath.

Table 2

Sample Selection Process Results

\begin{tabular}{clc}
\hline Number & \multicolumn{1}{c}{ Sample Selection Criteria } & Amount \\
\hline 1 & $\begin{array}{l}\text { Manufacturing companies listed on the Indonesia Stock Exchange } \\
\text { for the period 2016-2018. }\end{array}$ & 166 \\
\hline 2 & $\begin{array}{l}\text { Manufacturing companies that that don't distribute yearly reports in } \\
\text { rupiah currency }\end{array}$ & $(26)$ \\
\hline 3 & $\begin{array}{l}\text { Manufacturing companies that don't have total information } \\
\text { required in research : }\end{array}$ & $(3)$ \\
\hline a. & Not disclosing corporate social responsibility activities & $(70)$ \\
\hline b. & There is no managerial ownership & $(17)$ \\
\hline c. & Have no net profit & $(21)$ \\
\hline d. & $\begin{array}{l}\text { Not publishing sustainability reports in a row during the 2016-2018 } \\
\text { period }\end{array}$ & 29 \\
\hline Final data count & 3 \\
\hline Research year & 87 \\
\hline Number of samples during the study period &
\end{tabular}

Source: IDX and edited by the author (2020)

\section{Data Collection Technique}

Data collection techniques are ways to get the data needed by researchers in conducting research (Sugiyono, 2016: 137). Information assortment method in this examination is documentation procedure. Documentation strategies are completed by gathering, examining and breaking down auxiliary information that contains data required in research (Sugiyono, 2016: 240). The information utilized in this investigation is optional information as yearly reports of manufacturing 
Corporate Social Responsibility, Investment Decisions, and Managerial Ownership on Value of The Company : Evidence From Indonesia

Ardillah \& Thenia

organizations recorded on the Indonesia Stock Exchange which are sourced from the Indonesia Stock Exchange (IDX) site and different information sources from diaries and other writing books.

\section{Value of The Company}

Value of the company is an investor's view of an organization identified with share prices. An organization is said to have great worth on the off chance that it has great execution of performance, since investor will in general be keen on putting their offers in organizations that have great execution in expanding organization esteem. Along these lines, the higher the stock value, the higher the value of the organization (Dewi, 2017). In this examination, the value of the organization is estimated utilizing the proportion of Price to Book Value (PBV) or the book value of the organization that can cause the market to have faith in the organization's possibilities.

The Price to Book Value (PBV) proportion broke down is a correlation between share price in a period with the book worth of value acquired from the organization's balance sheet in a specific period (Khoirunnisa, 2018). This ratio explains that the market price of a stock in its book value can give an indication of the investor's view of a company. The reason for using the Price to Book Value (PBV) ratio is because the book value has a relatively stable measure that can be compared with market price. Another reason to use this ratio is because book value is able to provide consistent accounting standards for all companies. In addition, a high Price to Book Value (PBV) will also make the market believe in the company's prospects in the future. Price to Book Value (PBV) can be calculated using the following formula (Sudana, 2013:23).

Price to Book Value $=$ Market Value Per Share $/$ Book Value Per Share

Book value per share can be obtained by the following formula (Sudana, 2013:23).

Book Value Per Share $=$ Total Equity $/$ Total Outstanding Share

\section{Corporate Social Responsibility}

Corporate social responsibility is a type of corporate duty in fixing social imbalance and ecological harm that happens around the organization because of the organization's functional exercises. The more types of duty the organization embraces to the climate, the organization's picture will increment and furthermore affect expanding value of the company (Sudarma \& Darmayanti, 2021). Corporate social responsibility can be estimated utilizing the Corporate Social Responsibility Disclosure Index (CSRDI) intermediary dependent on the Global Reporting Initiative (GRI). Corporate social responsibility disclosure indicators consisting of 91 items using 6 (six) performance indicators, namely (Hadyarti, 2019):

1. Economy (AEC) which consists of 9 items

2. Environment (AEN) consisting of 34 items

3. Manpower (ALA) which consists of 16 items

4. Human Rights (AHR) which consists of 12 items

5. Community Social which consists of 11 items

6. Product Responsibility which consists of 9 items 
Corporate social responsibility is estimated utilizing a rundown of social duty revelations, to be specific by giving a score of 0 (zero) for every thing that isn't unveiled in the organization's yearly report and giving a score of 1 (one) for everything revealed in the organization's yearly report (Murnita \& Putra, 2018). The Corporate Social Responsibility Disclosure Index (CSRDI) is formulated with the following calculation (Wulandari et al., 2016).

Information :

$\mathrm{Xij}=$ Number of corporate social responsibility items uncovered by the organization

nj $=$ Maximum number of items for corporate social responsibility exposure

\section{Investment Decision}

The investment decision is one of the decisions that must be taken by financial managers to allocate existing funds in order to bring profits in the future (Tanto et al., 2019). Organizations that have high speculation choices will actually want to impact investors' understanding of the company, so comprehension of the organization, in order to build the interest for the organization's offers. In this way, the higher the investor's interest in putting resources into an organization, the investment decision will affect expanding the value of the company (Pertiwi et al., 2016). Investment decisions in this study are proxied by Price Earning Ratio (PER). Price Earning Ratio (PER) is determined by contrasting the price per share and the income procured from each share. Investors will see the organization's capacity to produce income from each one of the assets contributed by the company. If the Price Earning Ratio (PER) is high, then investors will assume that the company is able to allocate its funds properly and in the end it will increase the value of the company. Price Earning Ratio (PER) is formulated with the following calculation (Somantri \& Sukardi, 2019).

Price Earning Ratio (PER) = Share Price / Earnings Per Share

\section{Managerial Ownership}

Managerial ownership is the is the level of divide for share proprietorship between executives, officials, and all straightforwardly engaged with settling on organization choices (Dewi, 2017). Through managerial ownership, managers will be motivated to provide more optimal performance in operating the company, because managers have rights and obligations attached to both the shares they own and the company. When a manager is able to provide more optimal performance, then this will directly affect the increase in company performance and also increase the value of the company (Gayatri et al., 2016). In this study, managerial ownership is measured by calculating the percentage $(\%)$ of shares owned by commissioners, boards of directors and managers to the number of outstanding shares. The formula for calculating managerial ownership is as follows (Sudarma \& Darmayanti, 2021).

MO = Total Share Owned By Manager, Directors, and Commissioners / Total Outstanding Share

\section{Data Analysis Method}

Data analysis is a process of systematically searching and compiling from data that has been obtained through various data collection techniques, so that it is easy to understand and inform 
other parties (Sugiyono, 2016: 244). The data analysis method used in this research is quantitative analysis using statistical methods. The analysis in the study was carried out using SPSS version 25 software. The data analysis method used in this study was multiple linear regression analysis to determine whether there was an influence of several independent variables on the dependent variable (Ghozali, 2018).

\section{RESULT AND DISCUSSION}

Based on the results of descriptive statistical tests on corporate social responsibility, the lowest value was 0.1098901 and the highest value was 0.2857143 , while the average value obtained was 0.171908547 with a standard deviation of 0.0435057871 . The company that has the highest percentage of corporate social responsibility is Fajar Surya Wisesa with a percentage amount of $29 \%$. Meanwhile, the companies that have the lowest percentage of corporate social responsibility are Sekar Laut Tbk and Siantar Top Tbk at 11\%. From the results of the analysis, the average value is 0.171908547 , this means that the company has disclosed its corporate social responsibility activities, which is $17 \%$, meaning that the company has taken part in improving social inequality and environmental damage that occurred around the company due to the company's operational activities. This indicates that the mean value can be used as a representation of the entire data. The standard deviation is a reflection of the average deviation of the data from the mean.

The investment decision obtained a minimum value of 3.0078076 and a maximum value of 42.8659747, while the mean value obtained was 16.836777767 with a standard deviation of 8.7760052162. The company that has the highest investment decision is Lion Metal Works Tbk with a percentage of $4287 \%$. Meanwhile, the company that has the lowest percentage of investment decisions is Kedawung Setia Industrial Tbk at 301\%. From the results of the analysis, it can be seen that the mean value is 16.836777767 , this means that the company has implemented an investment decision of $17 \%$, meaning that the financial manager has made the decision to allocate existing funds to bring profits in the future. The average value is greater than the standard deviation value, this indicates that the mean value can be used as a representation of the entire data. The standard deviation is a reflection of the average deviation of the data from the mean.

The results of descriptive statistical tests on managerial ownership obtained the lowest value of 0.0000933 and the highest value of 0.3451344 , while the average value obtained was 0.080101115 with a standard deviation of 0.1032648575 . The company that has the highest managerial ownership is Indo Acidatama Tbk with a managerial ownership percentage of $35 \%$. Meanwhile, the company that has the lowest percentage of managerial ownership is Kalbe Farma Tbk at $0.00933 \%$. The average value is 0.080101115 , this means that the company's shares have been owned by managers, boards of directors and commissioners by $8 \%$. It can be concluded that managers, boards of directors and commissioners have taken part in supervising company performance to increase the value of the company although there are still many companies that have a low percentage of managerial ownership. The definition of the standard deviation is a reflection of the average deviation of the data from the mean which also describes the magnitude of the data variation. The average value of managerial ownership is smaller than the standard deviation value, this larger standard deviation value indicates that managerial ownership has a larger variation in the data, so the mean value is a poor representation of the overall data. 
The value of the company obtained a minimum value of 0.2281336 and a maximum value of 5.7016536, while the mean value obtained was 1.682218316 with a standard deviation of 1.3811070957. The company that has the highest value of the company is Kalbe Farma Tbk with a value of the company percentage of $570 \%$. Meanwhile, the company that has the lowest percentage of value of the company is Intanwijaya International Tbk at $23 \%$. From the results of the analysis, it can be seen that the mean value is 1.682218316 or $168 \%$, this means that most companies have good corporate values. This indicates that the mean value can be used as a representation of the entire data. The standard deviation is a reflection of the average deviation of the data from the mean.

\section{Classical Assumption Tests}

The results of the normality test show the asymp value. sig. (2-tailed) of $0.197>$ alpha 0.05 . It can be interpreted that the residual data on the proportion of corporate social responsibility, investment decisions and managerial ownership are declared normally distributed. The results of the multicollinearity test show that corporate social responsibility, investment decisions and managerial ownership do not have multicollinearity problems so that data on corporate social responsibility, investment decisions and managerial ownership are well used in the regression model. Heteroscedasticity test results show that the significant value of corporate social responsibility, investment decisions and managerial ownership is greater than $5 \%$, so it can be concluded that there is no heteroscedasticity in the regression model. The results of the autocorrelation test show that the Durbin-Watson value of 0.556 lies between -2 to 2 which can be concluded that this regression model does not have autocorrelation.

\section{Coefficient of Determination Test}

The results of the coefficient of determination (R2) show the Adjusted R2 value of 0.298. Thus, it can be concluded that corporate social responsibility, investment decisions and managerial ownership can explain $29.8 \%$ of the variation in value of the company, while the remaining $70.2 \%$ is explained by the variable others that are not included in the regression equation model.

\section{Hypothesis Test}

The results of the hypothesis test in this study which aims to prove the influence of corporate social responsibility, investment decisions and managerial ownership on value of the company are presented in table 3 below.

Table 3

Hypothesis Test Results 
Corporate Social Responsibility, Investment Decisions, and Managerial Ownership on Value of The Company : Evidence From Indonesia

Ardillah \& Thenia

\begin{tabular}{llrr}
\hline \hline \multicolumn{1}{c}{ Model } & \multicolumn{1}{c}{$\begin{array}{c}\text { Unstandardized } \\
\text { Coefficients }\end{array}$} & \multirow{2}{*}{ Sig. Value } \\
\cline { 3 - 3 } & & \multicolumn{1}{c}{$\mathrm{B}$} & \\
\hline \multirow{2}{*}{1} & (Constant) & -1.577 & 0.493 \\
\cline { 2 - 3 } & Corporate social responsibility & 0.204 & 0.000 \\
\cline { 2 - 3 } & Investment Decision & 0.742 & 0.253 \\
\cline { 2 - 3 } & Managerial Ownership & -0.037 & \\
\hline
\end{tabular}

Based on the results of multiple regression analysis in table 3, the regression equation used in this study is as follows.

VALUE $=-1.577+0.204 \mathrm{CSR}+0.742 \mathrm{IO}-0.037 \mathrm{MO}+\mathrm{e}$

Based on the results of the partial test ( $t$ test) in table 3, the results of the analysis of the influence of the independent variable partially on the dependent variable are explained as follows.

1. Corporate social responsibility has a significance value of 0.493 which means a significance value of more than 0.05 which causes Ha1 in this study to be rejected, namely corporate social responsibility has no influence on value of the company.

2. The investment decision has a significance value of 0.000 which means the significance value is less than 0.05 and the Beta value is positive, namely 0.742 which causes $\mathrm{Ha} 2$ in this study to be accepted and has a positive relationship, namely investment decisions have a positive influence on value of the company.

3. Managerial ownership has a significance value of 0.253 , which means a significance value of more than 0.05 which causes $\mathrm{Ha} 3$ in this study to be rejected, namely managerial ownership has no influence on value of the company.

\section{The Influence of Corporate Social Responsibility on Value of The Company}

The results of the corporate social responsibility test prove that corporate social responsibility has no influence on value of the company. This is not in line with research conducted by Dewi \& Sanica (2017) and Andreas \& Adiputra (2019) which state that corporate social responsibility has a positive influence on value of the company, but the results of this study are in line with research conducted by Puspaningrum (2017) and (Sudarma \& Darmayanti, 2021) which states that corporate social responsibility has no influence on value of the company.

The rejection of the hypothesis in this study occurs because the disclosure of corporate social responsibility by the company is relatively low, because this activity is still voluntary in Indonesia so that companies do not consider corporate social responsibility as an aspect of business strategy to gain profits and increase value of the company. In addition, not all companies fully disclose corporate social responsibility in their annual reports or issue separate corporate social responsibility reports. Another chance is that investors don't completely trust in the divulgence of corporate social responsibility did by the organization in light of the fact that up to this point there are as yet numerous cases identified with ecological, social and monetary issues, so investors consider that the exposure of corporate social responsibility is just a custom and can't guarantee that the organization has great corporate value.

Corporate social responsibility isn't identified with signalling theory in light of the fact that the aftereffects of this investigation show that executing social responsibility does not influence the value of the company. Information on corporate social responsibility is a is likewise not generally 
remembered for the organization's yearly report or a different report on corporate social responsibility. Corporate social responsibility is is less ready to give consolation to organizations to give data to outside parties identified with dynamic that can influence the value of the company and changes in the organization's stock price. It it very well may be presumed that the divulgence of corporate social duty has no impact in expanding the value of the company.

\section{The Influence of Investment Decisions on Value of The Company}

The results of testing investment decisions prove that investment decisions have a positive influence on value of the company. The results of this study are not in line with the research conducted by Dewi \& Wirasedana (2018) and (Suryandani, 2018), but are consistent and strengthen the research conducted by (Suroto, 2015) and (Tanto et al., 2019) which states that investment decisions have a positive influence on value of the company.

The acceptance of the hypothesis in this study is due to high investment decisions indicating that the company's investment and company growth prospects are in good condition so as to increase the demand for shares in the company. The investment decisions taken by the company are also an alternative for companies to spend their funds outside of operational activities in order to gain profits for the company in the future. The higher the venture choice set by the organization, the higher the chance for the company to get opportunity for benefit. Subsequently, directors should keep up with the improvement of ventures so they can accomplish organization objectives through the welfare of shareholders and can build value of the company.

In light of the fact that the consequences of this examination, it can be shown that investment decisions influence value of the company. If that the organization can settle on the right investment decisions, the company will will acquire benefits and the organization's resources will create ideal execution in order to give a positive signal to investors, which will expand stock price and value of the company. So it tends to be presumed that investment decisions have have an impact in expanding value of the company.

\section{The Influence of Managerial Ownership on Value of The Company}

The test results of managerial ownership prove that managerial ownership has no influence on value of the company. The results of this study are different from the research conducted by (Gayatri et al., 2016) and (Sudarma \& Darmayanti, 2021) which state that managerial ownership has a positive influence on value of the company. However, the results of this study are in line with and support previous research conducted by (Suastini et al., 2016) and (Rely \& Purwanti, 2018) which stated that managerial ownership had no influence on value of the company.

The rejection of the hypothesis in this study occurs because the share ownership owned by managers, boards of directors and commissioners is relatively small or does not have many shares in the company. The low share ownership by managers, boards of directors and commissioners means that the performance of managers as a minority has not been able to actively participate in making decisions in the company, so it does not affect the value of the company. Low share ownership by managers, boards of directors and commissioners causes managers to prioritize their goals as managers rather than as shareholders and makes managers' performances tend to have no influence on value of the company. 
Based on the discussion that has been stated, managerial ownership is not always related to agency theory because the results of this study indicate that the presence of stock ownership by managers, boards of directors and commissioners does not affect value of the company. Share ownership by managers who act as agents as well as principals cannot in fact reduce agency conflicts that can occur, because relatively high managerial ownership is not a benchmark that managers will not be concerned with their own interests. So it can be concluded that the existence of managerial ownership in a company is not fully influential in increasing the value of the company.

\section{CONCLUSION}

Corporate social responsibility has no effect on value of the company. It tends to be reasoned that the revelation of corporate social responsibility by the organization can't ensure that the organization will keep away from cases identified with ecological, social and monetary issues and are less ready to give support to give data to external parties related to decision making that can influence the value of the company. Investment decisions have a positive effect on value of the company. It tends to be reasoned that a high speculation choice demonstrates that the organization's investment and company growth possibilities are in acceptable condition to expand the demand for shares in the organization and furthermore affect expanding the value of the company. Managerial ownership has no effect on value of the company. It can be concluded that managerial ownership cannot affect the value of the company because the shares owned by managers, boards of directors and commissioners are still relatively small, so it cannot guarantee that managers are more concerned with their goals as a manager than as shareholders and make managers' performance tend to have no effect on the value of the company.

For management, this research is expected to be a reference in decision making by management, especially regarding the impact of every decision taken related to company value, increasing disclosure of corporate social responsibility, optimizing investment decision making and considering managerial share ownership so that managers, boards of directors and commissioners can participate fully active in making decisions in a company. For investors, the results of this study are expected to be used as consideration for making investment decisions by assessing what things or indicators can have an effect on increasing the value of the company. Investors should also conduct a more in-depth analysis before investing their funds in a company such as studying the history of the company and the factors that affect the value of the company. For further researchers, it is expected to add other indicators such as funding decisions, company size, other corporate governance indicators, using companies with other sectors besides manufacturing such as the mining sector, property sector, financial sector or real estate sector, using other sample criteria for comparison results to make the sample data more visible and more varied, increasing the number of research periods so that they are longer for example 5 years or 6 years, using different measurement methods or adding measurement methods for company value, namely Tobin's Q or Price Earnings Ratio (PER) and can collect more references in order to provide better research results.

\section{REFERENCE}

Abdelfattah, T., \& Aboud, A. (2020). Tax avoidance, corporate governance, and corporate social responsibility: The case of the Egyptian capital market. Journal of International Accounting, Auditing and Taxation, 38, 100304. https://doi.org/10.1016/j.intaccaudtax.2020.100304 
Corporate Social Responsibility, Investment Decisions, and Managerial Ownership on Value of The Company : Evidence From Indonesia

Ardillah \& Thenia

Andreas, K., \& Adiputra, I. G. (2019). Pengaruh Keputusan Keuangan Dan Corporate Social Responsibility Terhadap Nilai Perusahaan Manufaktur. Jurnal Manajerial Dan Kewirausahaan, I(3), 524-531.

Astuti, C. W., \& Nugrahanti, Y. W. (2015). Pengaruh Pengungkapan Corporate Social Responsibility Terhadap Reaksi Pasar. Jurnal Dinamika Akuntansi Kenangan Dan Perbankan, 4(2), 90-105. https://unisbank.ac.id/ojs/index.php/fe9/article/view/4589

Chung, C. Y., Jung, S., \& Young, J. (2018). Do CSR Activities Increase Firm Value? Evidence from the Korean Market. Sustainability, MDPI, Open Access Journal, 10(9), 3-22. https://ideas.repec.org/a/gam/jsusta/v10y2018i9p3164-d167755.html

Dewi, K., \& Sanica, I. G. (2017). Pengaruh Kepemilikan Institusional, Kepemilikan Manajerial, dan Pengungkapan Corporate Social Responsibility terhadap Nilai Perusahaan Pada Perusahaan Manufaktur yang Terdaftar di Bursa Efek Indonesia. JLAB Jurnal Ilmiah Akuntansi Dan Bisnis, 2(1), 1-26. https://doi.org/https://doi.org/10.38043/jiab.v2i1.175

Dewi, L., \& Wirasedana, I. W. P. (2018). Pengaruh Keputusan Investasi, Keputusan Pendanaan, Kebijakan Dividen dan Tingkat Inflasi terhadap Nilai Perusahaan. E-Jurnal Akuntansi, 23(2), 813-841. https://doi.org/10.24843/EJA.2018.v23.i02.p01

Elgebeily, E., Guermat, C., \& Vendrame, V. (2021). Managerial optimism and investment decision in the UK. Journal of Behavioral and Experimental Finance, 31, 100519. https://doi.org/10.1016/j.jbef.2021.100519

Gayatri, I. A., Astika, I. . P., \& Suputra, I. D. G. D. (2016). Kepemilikan Manajerial dan Modal Intelektual Sebagai Prediktor Perataan Laba dan Implikasinya Terhadap Nilai Perusahaan. EJournal of Economics and Business, Udayana University Bali, 5(10), 3231-3266. https://ojs.unud.ac.id/index.php/EEB/article/view/20340

Hidayah, N. (2017). Pengaruh Investment Opportunity Set (IOS) dan Kepemilikan Manajerial Terhadap Nilai Perusahaan Pada Perusahaan Property dan Real Estat di Bursa Efek Indonesia. Jurnal Akuntansi, 19(3), 420. https://doi.org/10.24912/ja.v19i3.89

Jarjir, S. L., Nasreddine, A., \& Desban, M. (2020). Corporate social responsibility as a common risk factor. Global Finance Journal, September, 100577. https://doi.org/10.1016/j.gfj.2020.100577

Meidiawati, K., \& Mildawati, T. (2016). Pengaruh Size, Growth, Profitabilitas, Struktur Modal, Kebijakan Dividen Terhadap Nilai Perusahaan. Jurnal Ilmu Dan Riset Akuntansi, 5(2), 1-16. http://jurnalmahasiswa.stiesia.ac.id/index.php/jira/article/view/1536

Murnita, P. E. M., \& Putra, I. M. P. D. (2018). Pengaruh Corporate Social Responsibility terhadap Nilai Perusahaan dengan Profitabilitas dan Leverage Sebagai Variabel Pemoderasi. E-Jurnal Akuntansi, 23(2), 1470-1494. https://doi.org/10.24843/EJA.2018.v23.i02.p25

Pavez, I., Kendall, L. D., \& Laszlo, C. (2020). Positive-impact companies: Toward a new paradigm of value creation. Organizational Dynamics, 2019, 100806. https://doi.org/10.1016/j.orgdyn.2020.100806

Pertiwi, P. J., Tommy, P., \& Tumiwa, J. R. (2016). The Influence of Debt Policy, Investment Decisions and Profitability on the Value of Food and Beverages Companies listed on the Indonesia Stock Exchange. Jurnal Riset Ekonomi, Manajemen, Bisnis Dan Akuntansi (EMBA), 4(1), 1369-1380. https://doi.org/https://doi.org/10.35794/emba.4.1.2016.12357 
Corporate Social Responsibility, Investment Decisions, and Managerial Ownership on Value of The Company : Evidence From Indonesia

Ardillah \& Thenia

Puspaningrum, Y. (2017). Pengaruh Corporate Social Responsibility dan Kepemilikan Manajerial Terhadap Nilai Perusahaan dengan Profitabilitas dan Ukuran Perusahaan Sebagai Variabel Moderating (Studi Empiris Pada Perusahaan Pertambangan di Bursa Efek Indonesia). Journal of Accounting UNY, 5(2). https:/ / eprints.uny.ac.id/17160/

Rahayu, M., \& Sari, B. (2018). Faktor-Faktor yang Mempengaruhi Nilai Perusahaan. Journal of Social and Humanities, Universitas Persada Indonesia YAI, 2(1), 69-76. https://journals.upiyai.ac.id/index.php/ikraith-humaniora/article/view/73

Rahdari, A., Sheehy, B., Khan, H. Z., Braendle, U., Rexhepi, G., \& Sepasi, S. (2020). Exploring global retailers' corporate social responsibility performance. Heliyon, 6(8), e04644. https://doi.org/10.1016/j.heliyon.2020.e04644

Rely, G., \& Purwanti, A. (2018). An Effecting of Corporate Social Responsibility, Managerial Ownership, Institutional Ownership of Firm Values Towards Real Earnings Management. Journal of Finance and Accounting Research, IBI KKG, 9(18), 66-77. https://www.iiste.org/Journals/index.php/RJFA/article/view/44432

Rinnaya, I. Y., Andini, R., \& Oemar, A. (2016). Pengaruh Profitabilitas, Rasio Aktivitas, Keputusan Pendanaan Keputusan Investasi Terhadap Nilai Perusahaan (Studi Empiris Pada Perusahaan Manufaktur Yang Terdaftar Di BEI Tahun 2010-2014). Journal Of Accounting Pandanaran, 2(2), 1-18. http://jurnal.unpand.ac.id/index.php/AKS/article/view/438

Singh, P., Sethuraman, K., \& Lam, J. (2017). Impact of Corporate Social Responsibility Dimensions on Firm Value: Some Evidence from Hong Kong and China. Sustainability, 9(9), 1532. https://doi.org/10.3390/su9091532

Somantri, I., \& Sukardi, H. A. (2019). Pengaruh Keputusan Investasi, Kebijakan Hutang Dan Kebijakan Dividen Terhadap Nilai Perusahaan. JEMPER Jurnal Ekonomi Manajemen Perbankan), 1(1), 1. https://doi.org/10.32897/jemper.v1i1.125

Suastini, N. M., Purbawangsa, I. B. A., \& Rahyuda, H. (2016). Pengaruh Kepemilikan Manajerial dan Pertumbuhan Perusahaan Terhadap Nilai Perusahaan Pada Perusahaan Manufaktur di Bursa Efek Indonesia (Struktur Modal Sebagai Variabel Moderasi). E-Jurnal Ekonomi Dan Bisnis Universitas Udayana, 5(1), 143-172. https://ojs.unud.ac.id/index.php/EEB/article/view/17817

Sudarma, I. K. G. A. M., \& Darmayanti, N. P. A. (2021). Pengaruh CSR, Kepemilikan Manajerial dan Profitabilitas Terhadap Nilai Perusahaan Sektor Pertambangan Pada Indeks Kompas 100. E-Jurnal Manajemen, 6(4), 1906-1932. https://ojs.unud.ac.id/index.php/Manajemen/article/view/28212

Suroto, S. (2015). Pengaruh Keputusan Investasi, Keputusan Pendanaan dan Kebijakan Dividen Terhadap Nilai Perusahaan (Studi Empiris Pada Perusahaan LQ-45 yang Terdaftar di Bursa Efek Indonesia Periode Februari 2010-Januari 2015). Scientific Journal of UNTAG Semarang, 4(3), 100-117. http://jurnal.untagsmg.ac.id/index.php/sa/article/view/174

Suryandani, A. (2018). Pengaruh Pertumbuhan Perusahaan, Ukuran Perusahaan, dan Keputusan Investasi terhadap Nilai Perusahaan pada Perusahaan Sektor Property dan Real Estate. Business Management Analysis Journal (BMAJ), 1(1), 49-59. https://jurnal.umk.ac.id/index.php/bmaj/article/view/2682

Tanto, T. I. A., Simanjuntak, A. M. A., \& Pangayow, B. J. C. (2019). Pengaruh Keputusan Investasi, Keputusan Pendanaan Dan Kebijakan Deviden Terhadap Nilai Perusahaan. Journal of 
Corporate Social Responsibility, Investment Decisions, and Managerial Ownership on Value of The Company : Evidence From Indonesia

Ardillah \& Thenia

Accounting and Finance, Cenderawasih University,
https://doi.org/http://dx.doi.org/10.52062/jakd.v14i1.1450,
Tarczynski, W., Tarczynska-Luniewska, M., \& Majewski, S. (2020). The value of the company and
its fundamental strength. Procedia Computer Science, 176, 2685-2694.
https://doi.org/10.1016/j.procs.2020.09.331

Widianingsih, D. (2018). Kepemilikan Manajerial, Kepemilikan Institusional, Komisaris Independen, serta Komite Audit pada Nilai Perusahaan dengan Pengungkapan CSR sebagai Variabel Moderating dan Firm Size sebagai Variabel Kontrol. Jurnal Akuntansi Dan Pajak, 19(1), 38. https://doi.org/10.29040/jap.v19i1.196

Widiastari, P. A., \& Yasa, G. W. (2018). Pengaruh Profitabilitas, Free Cash Flow, dan Ukuran Perusahaan Pada Nilai Perusahaan. E-Jurnal Akuntansi, 23(2), 957-981. https://doi.org/10.24843/EJA.2018.v23.102.p06

Wiguna, R. A., \& Yusuf, M. (2019). Pengaruh Profitabilitas dan Good Corporate Governance Terhadap Nilai Perusahaan. ECONBANK: Journal of Economics and Banking, 1(2), 158-173. https://doi.org/10.35829/econbank.v1i2.47

Wulandari, A. A., Ramantha, I. W., \& Wirakusuma, M. G. (2016). Dampak Moderasi Profitabilitas Terhadap Pengaruh Corporate Social Responsibility pada Nilai Perusahaan Manufaktur. EJurnal Ekonomi Dan Bisnis Universitas Udayana, 5(7), 1889-1918. Corporate Social Responsibility, Profitability, Firm Value\%0A 